Print ISSN: 2288-4637 / Online ISSN 2288-4645

doi:10.13106/jafeb.2020.vol7.no12.501

\title{
Destination Loyalty Towards Bali
}

\author{
Diena Mutiara LEMY ${ }^{1}$, Adinoto NURSIANA², Rudy PRAMONO ${ }^{3}$
}

Received: September 01, 2020 Revised: October 26, 2020 Accepted: November 05, 2020

\begin{abstract}
The focus of this research was on Bali, Indonesia as an international tourist destination. The survey strategy involved self-administered questionnaires distributed to collect data and information supporting this research. The sampling method was non-probability convenience purposive sampling, which means that only those respondents who had visited Bali as a destination for more than two times for their holiday by the time the research was conducted were eligible to fill in the questionnaires. There were 300 questionnaires distributed, only 254 of which were valid. Interview was also conducted for data collection in this research. The structural equation modelling approach was used to analyze the data obtained from respondents, who had visited Bali at least two times. The outcomes of this research reveal a positive influence of push and pull motivational factors on tourist satisfaction. Moreover, a positive, significant correlation between satisfaction and destination loyalty can be seen in this research. With the aim to sustain and enhance destination competitiveness, the results of this research will be beneficial for stakeholders of Bali as a destination. This study helps stakeholders identify push and pull motivational factors in order to better prepare marketing strategies and utilize indicators of push and pull motivation that affect tourists' experience during their stay.
\end{abstract}

Keywords: COVID-19, Destination Loyalty, Pull Motivational Factors, Push Motivational Factors, Satisfaction, Tourist Destination

JEL Classification Code: D11, D47, E32, L83, Z33

\section{Introduction}

Tourism is one of the fastest growing industries in the world and is a major source of income for many countries. Tourism helps revitalize the local economy by becoming an industry that provides many jobs and requires a lot of labor (UNESCO, 2018). But in the latest outbreak of the novel coronavirus (COVID-19) pandemic has incontrovertibly locked down and instantly dampened the global economy. Tourism-related businesses such as food and beverages, travel and hotel businesses, among others, are mainly affected and badly malformed by it (Liew, 2020).

The recently discovered coronavirus, COVID-19, is an infectious disease. Coronaviruses, which can affect

${ }^{1}$ First Author. Department Hospitality and Tourism. Pelita Harapan University, Jakarta, Indonesia. Email: diena.lemy@uph.edu

${ }^{2}$ Management Department, Wiyatamandala School of Business, Jakarta Indonesia. Email: adinoto_n@yahoo.com

${ }^{3}$ Corresponding Author. Lecturer, Pelita Harapan University, Indonesia

[Postal Address: MH Thamrin Boulevard 1100, KIp. Dua, Kec. Klp. Dua,

Tangerang, Banten 15811, Indonesia] Email: rudy.pramono@uph.edu

(c) Copyright: The Author(s)

This is an Open Access article distributed under the terms of the Creative Commons Attribution Non-Commercial License (https://creativecommons.org/licenses/by-nc/4.0/) which permits unrestricted non-commercial use, distribution, and reproduction in any medium, provided the original work is properly cited. humans and a variety of other mammals and birds, were first discovered in 1965 and have been responsible for a number of outbreaks of diseases since then. The virus spreads directly or indirectly by tiny droplets from between individuals when someone with COVID-19 coughs, sneezes, or exhales. Directly, when a person coughs or exhales and the droplets are inhaled by another person, and indirectly when the droplets settle on objects or surfaces, which may infect other people who touch these objects or surfaces with their hands and then touch their eyes,nose or mouth (Jones \& Comfort, 2020). As a consequence, the hospitality and tourism operations of many countries have been virtually shut down and international travel (and, in some countries, domestic travel as well) has all but ceased. Indeed, air and sea travel (especially in the form of mega-ship cruises) has been highlighted as one of the main causes behind the rapid and global spread of the pandemic (Chinazzi et al., 2020).

In the midst of the Coronavirus (COVID-19) pandemic, tourism has become the most languishing business. For Bali itself, in particular, there is a potential loss of up to US\$ 9 billion (Indraini, 2020). It was stated that the number of domestic tourists on vacation last August experienced a tremendous decrease compared to the last year which could reach tens of thousands per day, down $81 \%$ over the same period last year. Even though the city government of Badung 
and the provincial government of Bali have made their best efforts to implement health protocols, it is a real challenge to gain public trust back (Prakoso, 2020).

Tourist loyalty and satisfaction play a significant role in supporting the tourism industry, which is expected to be successful and sustainable (Sadeh et al., 2012; Rohman, 2020). The challenge faced by a destination manager is to establish an effective strategy to create an attractive destination in the mind of tourists (Gursoy et al., 2014). It has been claimed that tourists can be lured with unique attractions to ensure their satisfaction and loyalty. To a destination, tourist loyalty plays a crucial part in the development of local tourist attractions (Huynh, 2018). Destination or tourist loyalty is described as current tourist's plan to return to a destination later, or the chance of he or she recommending a destination to other people (Neuts et al., 2013). This statement is supported by Valle et al. (2006), who investigated the correlation between tourist loyalty and destination satisfaction. The conclusion of the investigation is that the greater the tourist satisfaction, the greater is the likelihood that the tourists come back to a destination as well as recommend the destination to their relatives or friends (Huynh, 2018). Chi and Qu (2008) emphasized that it is important to determine the driving powers of destination loyalty to enable companies to figure out how to improve tourist loyalty to the destination, which most likely will lead to a performance improvement as well (Huynh, 2018). Many tourist destinations place a greater emphasis on repeat tourists than new ones since it is less expensive (Um et al., 2006).

There are psychological reasons that motivate people to travel away from home, and one of the well-accepted theories of motivation is the theory of push and pull motivation. This theory states that motivation can be classified into two forces, suggesting that people travel because they are pushed and pulled to do so by certain forces or causes (Dann, 1977, 1981). Uysal and Hagan (1993) stated that the theory explains how travellers are pushed by motivational factors that influence them in making travel decisions and how they are pulled or drawn by destination qualities. Dann's (1977) push and pull model has been used to investigate travel behaviours towards a series of push and pull situations (Murdy et al., 2018). Push factors have been recognized and believed to contain psychological forces, such as any willingness to escape, adventure, self-exploration and social contact, whereas pull factors contain attributes of a destination that are appealing to tourists. Travel satisfaction was used as a basis for the assessment of loyalty towards a destination, which, in this research, was Bali.

Bali is a famous destination in Indonesia. The Ministry of Tourism of Indonesia chose Bali as one of Three Great Destinations in Indonesia. To maintain the excellent performance in terms of destination loyalty and re-visit intention, a study regarding motivational factors affecting tourist intention to visit Bali is needed.

The objective of this research is to analyze the impact of travel motivation (push and pull factors) on travel satisfaction and destination loyalty and also evaluate the effect of COVID-19 on destination loyalty in the post pandemic era. This research's results are useful for destination managers in strategic marketing planning for the destination. They will also help managers and marketers improve their managing and marketing strategies in the destination area. This has a considerable importance since Bali is in the middle of a stiff competition with many emerging destinations, nationally and internationally. The relevant relationships between the three factors above will be investigated using the structural equation modelling approach that was replicated from Yoon and Uysal (2005).

Motivation can be defined as something that drives a person to do something to satisfy his or her needs (Moutinho, 2000). Motivation is also defined as a reason for someone's behaviour (Solomon, 2009). Heckhausen and Heckhausen (2018) also stated that a person's motivation to reach a certain target is shaped by people factor and situational factor, including expected results and impacts actions.

The effort to reach a goal constitutes a main part that forms a motivation (Beckmann \& Heckhausen, 2018). There are several reasons behind a person's decision to travel, for example, to enjoy entertainment, to go sightseeing, to visit a friend or relative, to enjoy free or leisure time, to engage in a professional or business activity, to attend a festival or event, to take a study tour, to join a fitness or educational activity, to encounter and study another culture or to conduct scientific research (Goeldner et al., 2000; Swanson \& Horridge, 2006). Filak \& Nicolini (2018) stated that the driving force of motivation often leads to improved or decreased results in relation to overall satisfaction a person acquires.

In tourism-related research, there is a well-known view that tourist motivation is closely linked to push and pull factors, which will affect destination choices. The concept of push and pull factors state that people are pushed and pulled to travel by two forces or components (Dann, 1981). This concept explains how people are pushed by motivational variables and how they are pulled or attracted by destination qualities to make travel decisions (Uysal \& Hagan, 1993). It can be said that push motivation is connected more to tourists' desire, while pull motivation is linked more to the attributes of a destination (Cha, McCleary, \& Uysal, 1995; Crompton, 1979; Dann, 1981; Oh, Uysal, \& Weaver, 1995). The push and pull motivation concept is widely used to study reasons for travelling (Li et al., 2013, Prayag \& Hosany, 2014).

In other words, push motivation is related more to inner or emotional aspects, while pull motivation is related to outer, situational or cognitive aspects. Crompton (1979) described 
push motivation as needs or wants that are related to the desire for retreat, leisure, prestige, health and fitness, adventure and social connection, family gathering and enthusiasm. Essentially, there are three purposes of traveling, namely commuting (usually from home to workplace), business and leisure (Keseru \& Macharis, 2017). To take leisure as an example of travel purpose as well as push motivation, pull motivation inspires a tourist to take pleasure in destination's atributes that are considered attractive, such as facilities, beaches, entertainment, cultural heritage, gardens, natural scenery and shopping centres. From the example above, it is believed that the concept of push and pull motivation plays a significant role in the study of tourist behavior. The findings of this research help understand tourist needs and wants that affect his or her motivation and satisfaction with a destination.

Sirgy (2010) discussed that life satisfaction can be boosted through participation in travel and tourism activities. Krippendorf (1987) found that tourists are self-oriented and they are more motivated by "going away from" rather than "going toward" something. Since tourists tend to be selforiented, it is crucial for the business to maximize travel satisfaction. According to Yuliana (2018), satisfaction is also known as an important predictor of loyalty because it affects a tourist's intention to revisit a destination as well as to give positive word of mouth (WOM). Uysal and Noe (2003) stated that it is important to evaluate physical attributes of a destination as well as make psychological interpretations on a destination because this reflects travel satisfaction with, and loyalty to, a destination. This statement is supported by McDowall (2010), who clearly stated that satisfaction is an important concept in understanding a destination's performance on the basis that recognition of any elements that will make tourists satisfied, will help increase any chances to attract loyal tourists to come. Thus, according to the above description, it can be concluded that a relationship between motivation and satisfaction does exist. Therefore, it can be hypothesised that:

\section{H1: Push motivation has an impact on tourist satisfaction} with a destination

H2: Pull motivation has an impact on tourist satisfaction with a destination

It is said that satisfaction is the foundation of developing loyalty (Ladhari, Brun and Morales, 2008; Cai and Chi, 2018; Mulyono et.al, 2020; Huyen and Binh, 2020). According to Oliver (1999), loyalty is a deeply-held tendency to re-promote a preferred brand or service regularly in the future, thereby causing repetitive brand purchase behaviour, regardless of situational impacts and marketing efforts having the ability to make a switching behavior. When a customer is loyal, he or she continues to buy the same brand, tends to buy more and is willing to recommend the brand to others. However, to make a customer loyal, he or she must be satisfied first with the product or services that he or she is consuming. Nasution and Mavondo (2008) suggested that the positive experience of the customer will make him or her satisfied and cause him or her to wish to return or stay longer in the establishment.

In relation to the tourism industry, loyalty serves as a key point that has been covered in literature (Almeida-Santana \& Moreno-Gil, 2018). It is described as tourists' purpose to come back to a place and their recommendation to other people (Yoon \& Uysal, 2005). There is a fundamental role saying that loyalty plays an important part in a destination's competitiveness (Weaver \& Lawton, 2011). However, to measure attitudinal loyalty to a destination, instead of using intention to come back, many tourism researchers have used tourists' recommendation to others (Chen \& Gursoy, 2001; Oppermann, 2000). Thus, it is necessary to consider both motivation and satisfaction as important factors to study. Therefore, it can be hypothesised that:

H3: Tourist satisfaction has a positive impact on destination loyalty

The proposed model of this study is as follows:

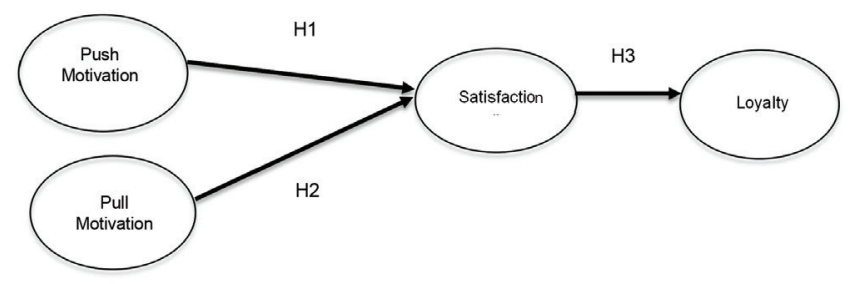

Figure 1: Research model

\section{Research Method}

This research was based on observed and measured phenomena (empirical research). It focused on the effects of push and pull motivation on satisfaction and destination loyalty. Factors involved are as follows: push motivation, pull motivation, tourist satisfaction and destination loyalty.

The strategies employed in this research were survey research and interview. The survey strategy involved selfadministered questionnaires distributed to collect data and information supporting this research. There were 300 questionnaires distributed, only 254 of which were valid. During the survey, some respondents were interviewed to gain more insight regarding their perception of Bali as a destination. In addition to that, an informant was interviewed to gain more perspective and information about how covid-19 impacting the destination loyalty, especially loyalty towards Bali. 
As a cross-sectional study, data was collected one time only in order to find the research answers (Sekaran and Bougie, 2013: 106). The sampling method of this study was non-probability convenience purposive sampling, which means that only respondents who had visited Bali as a destination more than two times for their holiday by the time the research was conducted were eligible to fill in the questionnaires. The location of the survey data collection was Lippo Karawaci, Tangerang. Most of the respondents were Indonesians, and some others were foreigners who had been staying in Indonesia for more than one year by the time the research was conducted. The questionnaires were adapted from the instruments employed in the study by Yoon and Uysal (2005), involving the following four main variables: push motivation, pull motivation, tourist satisfaction and destination loyalty. This proposed model was tested with the LISREL procedure of structural equation modelling (SEM) (Joreskog \& Sorbom, 2001).

\section{Research Results}

The data was analyzed using LISREL to test the proposed model through the structural equation modelling (SEM) method. From the data analysis, some results were obtained. Descriptive statistics and some data below show the standardized solution of relationships as well as t-values.

Figure 2 shows that all loading factors were above 0.50 . This means that the indicators were valid to be used to measure the variables. Afterwards, structural path analysis was used to test the research model and the hypotheses, the results are presented in Table 5 and Table 6 below:

According to Table 6, it can be concluded that the model for this research was good and fit.

From the results above, we can see that the data supports hypothesis 1 , which means that hypothesis 1 , that is, push motivation has a positive, significant impact on tourist satisfaction with a destination, is accepted $(\mathrm{t}$-value $=4.26)$. These results are different from those of the study of Yoon and Uysal (2005), revealing a negative relationship between push motivational factor and satisfaction. In this study, a higher level of tourists' push motivational factors will result in a higher level of satisfaction with a destination. The difference might occur because of tourists' differing characteristics and cultures. Most of the respondents were Indonesians, and some others were foreigners who had been staying in Indonesia for at least one year by the time this research was conducted.

Push motivational factors could be all things which has an effect on a tourist and drives him to travel, it works as an escape from daily routines of life or have a space for his or her 'self-orientedness'. Push factor indicators with the highest and lowest mean scores are 'feeling safe and secure' (4.5945) and 'finding thrills and excitement' (3.9173), respectively.
Table 1: Push Factors

\begin{tabular}{|c|c|}
\hline Indicators & $\begin{array}{c}\text { Mean } \\
\text { Statistic }\end{array}$ \\
\hline \multicolumn{2}{|l|}{ Factor 1 Exciting } \\
\hline Being physically active & 4.1417 \\
\hline Meeting people of the opposite sex & 4.1575 \\
\hline Finding thrills and excitement & 3.9173 \\
\hline Rediscovering myself & 4.3465 \\
\hline \multicolumn{2}{|l|}{ Factor 2 Knowledge/Education } \\
\hline Budget accommodation & 4.2362 \\
\hline Wide spaces to get away from the crowd & 4.2913 \\
\hline Variety of activities to see & 4.3976 \\
\hline Meeting new people & 4.3701 \\
\hline Being free to act how I feel & 4.3701 \\
\hline \multicolumn{2}{|l|}{ Factor 3 Relaxation } \\
\hline Doing nothing at all & 4.1850 \\
\hline Getting a change from a busy job & 4.3622 \\
\hline \multicolumn{2}{|l|}{ Factor 4 Achievement } \\
\hline Going to a place that friends have not yet & 4.5866 \\
\hline Talking about the trip & 4.3543 \\
\hline Rediscovering past good times & 4.4252 \\
\hline \multicolumn{2}{|l|}{ Factor 5 Family Togetherness } \\
\hline Visiting places my family came from & 4.4213 \\
\hline Visiting friends and relatives & 4.4764 \\
\hline Being together as a family & 4.5236 \\
\hline \multicolumn{2}{|l|}{ Factor 6 Escape } \\
\hline Getting away from the demands from home & 4.4488 \\
\hline Experiencing a simpler lifestyle & 4.5394 \\
\hline \multicolumn{2}{|l|}{ Factor 7 Safety/Fun } \\
\hline Feeling safe and secure & 4.5945 \\
\hline Being entertained and having fun & 4.5827 \\
\hline \multicolumn{2}{|l|}{ Factor 8 Away From Home \& Seeing } \\
\hline Feeling at home away from home & 4.5748 \\
\hline Seeing as much as possible & 4.4803 \\
\hline
\end{tabular}

Source: Adapted from Yoon and Uysal (2005)

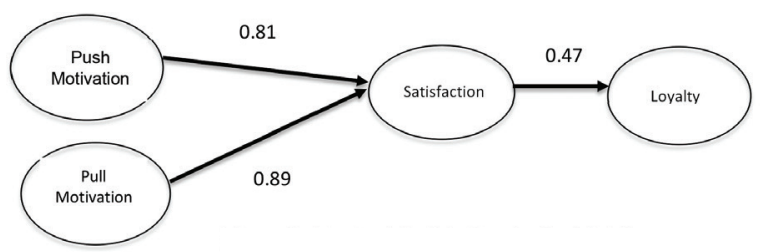

Figure 2: Structural Model - Standardized Solution 
Table 2: Pull Factors

\begin{tabular}{|c|c|}
\hline Indicators & $\begin{array}{c}\text { Mean } \\
\text { Statistic }\end{array}$ \\
\hline \multicolumn{2}{|l|}{ Factor 1 Atmosphere \& Activities } \\
\hline Beautiful rural areas & 4.5236 \\
\hline Exotic atmosphere & 4.5394 \\
\hline Amazing cultures & 4.3701 \\
\hline First class hotels & 4.3386 \\
\hline \multicolumn{2}{|l|}{ Factor 2 Wide Space \& Activities } \\
\hline Budget accommodation & 4.3425 \\
\hline Wide spaces to get away from crowd & 4.2362 \\
\hline Variety of activities to see & 4.3268 \\
\hline \multicolumn{2}{|l|}{ Factor 3 Small Size \& Reliable Weather } \\
\hline Manageable size & 4.2402 \\
\hline Reliable weather & 4.1693 \\
\hline Personal safety & 4.1693 \\
\hline \multicolumn{2}{|l|}{ Factor 4 Natural Scenery } \\
\hline Outstanding scenery & 4.3898 \\
\hline Mountainous/beaches & 4.3976 \\
\hline \multicolumn{2}{|l|}{ Factor 5 Different Culture } \\
\hline Interesting culture & 4.4409 \\
\hline Interesting \& friendly local people & 4.4134 \\
\hline Different culture & 4.2992 \\
\hline \multicolumn{2}{|l|}{ Factor 6 Cleanliness \& Shopping } \\
\hline Cleanliness & 4.1220 \\
\hline Shopping & 4.2441 \\
\hline Reliance or privacy & 4.2008 \\
\hline \multicolumn{2}{|l|}{ Factor 7 Nightlife \& Local Cuisine } \\
\hline Nightlife \& entertainment & 4.2795 \\
\hline Local cuisine & 4.1496 \\
\hline \multicolumn{2}{|l|}{ Factor 8 Interesting Town \& Village } \\
\hline Interesting town or village & 4.3583 \\
\hline Beautiful landscape & 4.2756 \\
\hline \multicolumn{2}{|l|}{ Factor 9 Water Activities } \\
\hline Seaside & 4.1929 \\
\hline Water sports & 4.3504 \\
\hline
\end{tabular}

Source: Adapted from Yoon and Uysal (2005)
Table 3: Satisfaction

\begin{tabular}{|l|c|}
\hline Indicators & Mean Statistic \\
\hline Expectation-satisfaction & 4.1102 \\
\hline Worth visiting & 4.3071 \\
\hline Comparison with other places & 4.5748 \\
\hline
\end{tabular}

Source: Adapted from Hunt (1983)

Table 4: Destination Loyalty

\begin{tabular}{|l|c|}
\hline Indicators & Mean Statistic \\
\hline $\begin{array}{l}\text { Recommendation to friends/ } \\
\text { relatives }\end{array}$ & 4.2717 \\
\hline Overall feeling to revisit & 4.4291 \\
\hline Positive word of mouth & 4.3622 \\
\hline
\end{tabular}

Source: Adapted from Oppermann (2000); Yoon and Uysal (2005) and Chen and Gursoy (2001)

Table 5: Structural Model Fit Test

\begin{tabular}{|c|c|c|c|}
\hline No. & Indicator & Standard & $\begin{array}{c}\text { Match } \\
\text { Rate }\end{array}$ \\
\hline \multirow[t]{5}{*}{1} & $\begin{array}{l}\text { Minimum Fit } \\
\text { function }\end{array}$ & & \\
\hline & $\begin{array}{l}\text { Chi-square = } \\
1117.96\end{array}$ & $P>0,05$ & Close fit \\
\hline & $(P=0,00)$ & & \\
\hline & $\mathrm{NCP}=673.80$ & $\begin{array}{l}\text { Small value and } \\
\text { narrow interval }\end{array}$ & Good fit \\
\hline & $(579.22-776.05)$ & & \\
\hline \multirow[t]{4}{*}{2} & RMSEA $=0,078$ & $\begin{array}{l}0 \leq \text { RSMEA } \geq \\
0.08\end{array}$ & Good fit \\
\hline & $\begin{array}{l}\text { C I for } \\
\text { RSMEA }(0,072 \\
-0,083)\end{array}$ & & \\
\hline & $P$-value for test of & $0.10 \leq P \geq 1.00$ & Close fit \\
\hline & close fit $=0.00$ & & \\
\hline \multirow[t]{4}{*}{3} & $\mathrm{NFI}=0,90$ & $0,90 \leq P \geq 1,00$ & Good fit \\
\hline & $\mathrm{NNFI}=0.93$ & $0,90 \geq P \leq 1,00$ & Good fit \\
\hline & $\mathrm{CFI}=0.93$ & $0,90 \leq P \geq 1,00$ & Good fit \\
\hline & $\mathrm{IFI}=0.93$ & $0,90 \leq P \geq 1,00$ & Good fit \\
\hline \multirow[t]{4}{*}{4} & $\mathrm{RFI}=0,88$ & $0,90 \leq P \geq 1,00$ & Close fit \\
\hline & $\mathrm{GFI}=0,78$ & $0,90 \geq P \leq 1,00$ & $\begin{array}{l}\text { Marginal } \\
\text { fit }\end{array}$ \\
\hline & AGFI $=0.74$ & $0,90 \geq P \leq 1,00$ & $\begin{array}{l}\text { Marginal } \\
\text { fit }\end{array}$ \\
\hline & PGFI $=0,65$ & $>0,50$ & Good fit \\
\hline
\end{tabular}

Source: Data Processing Results (2017) 
Table 6: Hypothesis Testing Results

\begin{tabular}{|l|l|c|c|c|l|}
\hline Hypotheses & \multicolumn{1}{|c|}{ Path } & $\begin{array}{c}\text { Standardized } \\
\text { Solution }\end{array}$ & t-value & Significant & \multicolumn{1}{|c|}{ Conclusion } \\
\hline 1 & & & & & \\
\hline 2 & $\begin{array}{l}\text { Push motivation (pushmot) } \\
\rightarrow \text { satisfaction (satisf) }\end{array}$ & 0.81 & 4.26 & Significant & $\begin{array}{l}\text { Data supports } \\
\text { hypothesis 1 }\end{array}$ \\
\hline 3 & $\begin{array}{l}\text { Pull motivation (pullmot) } \\
\text { satisfaction (satisfc) }\end{array}$ & 0.89 & 4.11 & Significant & $\begin{array}{l}\text { Data supports } \\
\text { hypothesis 2 }\end{array}$ \\
\hline
\end{tabular}

Source: Data Processing Results (2017)

Thus, these results will have a managerial implication in respect to how Bali as a destination can build trust and confidence in tourists' minds that the sense of safety and security can be guaranteed. A positive image is very important to the effort. Regarding the low score of 'finding thrills and excitement', the destination management of Bali should focus on the tourists who seek leisure for their vacation over those who look for adventure.

The results of hypothesis 2 testing are also favorable, which means that the hypothesis is accepted. Pull motivation has a positive, significant effect on satisfaction with $\mathrm{t}$-value $=4.11$. These findings are also different from those of the study of Yoon and Uysal (2005), showing that the relationship between the two constructs is negative. In this research, it can be said that an increased level of pull motivation will increase satisfaction. The push factor indicators with the highest and lowest mean scores are 'exotic atmosphere' (4.5394) and 'cleanliness' (4.1220), respectively. In response to these results, it is very important for the destination management of Bali to provide and maintain the quality of attractions that appeal to tourists, which in this case, are attractions that reflect the exotic atmosphere of Bali. Attention should be paid to historical heritage, natural attractions, food and culture. Extensive diversity of tourism resources will be an important tourism asset for tourist attractions to increase tourist satisfaction.

The results also support hypothesis 3 . Hence hypothesis 3 , that is, satisfaction has a positive, significant impact on loyalty, is accepted ( $\mathrm{t}$-value $=4.11$ ). This supports previous studies exploring the correlation between satisfaction and loyalty. It is confirmed that if tourists are satisfied with their experience with a destination, they will have an intention to be loyal to the destination. Thus, tourists who feel satisfied will visit Bali again. The highest and lowest mean scores of satisfaction are on the indicators 'comparison with other places' (4.5748) and 'expectation-satisfaction' (4.1102), respectively. These results reveal that tourists had compared Bali with other destinations and thought that in terms of satisfaction, Bali was the best destination even though expectation-satisfaction was not a factor that had the strongest effect on satisfaction. Thus, they had a great drive to revisit Bali. The managerial implication of these results is that the destination management of Bali should conduct further research about the factors which makes an impact on tourists to visit Bali and keep on improving and maintaining them. Bali's service excellence and cultural authenticity are examples in case. Moreover, an effort to minimize factors that lower tourist satisfaction also needs to be made.

Finally, the loyalty indicators with the highest and lowest mean scores are 'overall feeling to revisit' (4.4291) and 'recommendation to friends and relatives' (4.2717), respectively. These results show that tourists will show their loyalty by revisiting Bali on their next trip. It will be a better behavior compared to giving recommendation to friends and relatives. As a destination, Bali must work very hard to maintain tourists' trust, satisfaction and loyalty by practicing good tourism governance. Practicing sustainable tourism can also work as an alternative.

\section{Conclusion}

The results of this research proves that the tourist satisfaction with Bali is affected by push and pull motivation. In turn, satisfaction will influence tourist loyalty to the destination. This study helps stakeholders identify push and pull motivational factors in order to better prepare marketing strategies and utilize indicators of push and pull motivation that affect tourists' experience during their stay.

This research has some limitations. First, the respondents were mostly Indonesians, and some others were foreigners who had been residing in Indonesia for at least one year by the time this research was conducted. This may affect responses from the cultural perspective. It is feared that the reason why they became loyal to Bali as a destination was because they thought that it would not cost much to have a holiday there. Second, the sampling technique employed was non-probability convenience sampling. Therefore, it is suggested that future research should employ more varied respondents and explore further the indicators of push and pull motivational factors that have the greatest effect on the tourist satisfaction. 


\section{References}

Almeida-Santana, A. \& Moreno-Gil, S. (2018). Understanding tourism loyalty: Horizontal vs destination loyalty. Tourism Management, 65, 245-255.

Beckmann, J. \& Heckhausen, H. (2018). Motivation as a function of expectancy and incentive. In: J. Heckhausen, \& H. Heckhausen (Eds.), Motivation and Action. Cham, Switzerland: Springer International Publishing AG. doi: 10.1007/978-3-319-65094-4_5

Cha, S., McCleary, K., \& Uysal, M. (1995). Travel motivation of Japanese overseas travelers: A factor cluster segmentation approach. Journal of Travel Research, 34(1), 33-39.

Chai, R., \& Chi, C. G. (2018). The impacts of complain efforts on customer satisfaction and loyalty. The Service Industries Journal. doi: 10.1080/02642069.2018.1429415

Chen, J. S., \& Gursoy, D. (2001). An investigation of tourists' destination loyalty and preferences. International Journal of Contemporary Hospitality Management, 13(2), 79-85. doi: $10.1108 / 095961101103811870$

Chi, C. G. Q., \& Qu, H. (2008). Examining the structural relationships of destination image, tourist satisfaction and destination loyalty: An integrated approach. Tourism Management, 29(4), 624-636.

Chinazzi, M., et al. (2020). The effect of travel restrictions on the spread of the 2019 novel coronavirus (COVID-19) outbreak. Science, 368(6489), 395-400. https://doi.org/10.1126/science. aba9757

Crompton, J. L. (1979). Motivations for Pleasure Vacations. Annals of Tourism Research, 6(4), 408-424.

Dann, G. M. (1977). Anomie ego-enhancement and tourism. Annals of Tourism Research, 4(4), 184-194.

Dann, G. M. (1981). Tourism motivations: An appraisal. Annals of Tourism Research, 8(2), 189-219.

Filak, V. F., \& Nicolini, K. M. (2018). Differentiations in motivation and need satisfaction based on course modality: A selfdetermination theory perspective. Educational Psychology. doi: 10.1080/01443410.2018.1457776

Goeldner, C. R., Ritchie, J.R.B. \& McIntosh, R.W. (2000). Tourism: Principles, practices, philosophies (8th ed.). Hoboken, NJ: John Wiley.

Gursoy. D., Chen, J. S., \& Chi, C. G. (2014). Theoretical examination of destination loyalty formation. International Journal of Contemporary Hospitality Management, 26(5), 809-827.

Heckhausen, J. \& Heckhausen, H. (2018). Motivation and Action. Cham, Switzerland: Springer International Publishing AG. doi: 10.1007/978-3-319-65094-4_1

Huyen, L. H. B., Binh, T. L. (2020) Impact of Destination Image and Satisfaction on Tourist Loyalty: Mountain Destinations in Thanh Hoa Province, Vietnam. Journal of Asian Finance, Economics and Business, 7(4), 185-195. https: //doi. org/10.13106/jafeb.2020.vol7.no4.185
Huynh, Q. L. (2018). A thorough assessment of the casual relationship from tourist satisfaction to destination loyalty: A study in Tra Vinh. International Journal of Economics and Financial Issues, 8(2), 191-197.

Indraini, A. (2020). Bali Tourism Loss of IDR 135 T Hit by Corona. accessed on October 12, 2020, retrieved from https://finance. detik.com/berita-ekonomi-bisnis/d-4989864/pariwisata-balirugi-rp-135-t-dihantam-corona.

Jones, P., \& Comfort, D. (2020). The COVID-19 crisis and sustainability in the hospitality industry. International Journal of Contemporary Hospitality Management. https://doi. org/10.1108/IJCHM-04-2020-0357.

Jöreskog, K.G., Sörbom, D., Du Toit, S.H.C. \& Du Toit, M. (2001). LISREL 8: New statistical features (Third Printing with Revisions). Lincolnwood, IL: Scientific Software International, Inc.

Keseru, I., \& Macharis, C. (2017). Travel based multitasking: Review of the empirical evidence. Transport Reviews. doi: 10.1080/01441647.2017.1317048

Krippendorf, J. (1987). The holiday markers: Understanding the impact of leisure and travel. Wiltshire, England: Heinemann Professional Publishing.

Ladhari, R., Brun, I., \& Morales, M. (2008). Determinants of dining satisfaction and post-dining behavioral intentions. International Journal of Hospitality Management, 27(4), 563-573.

Li, X. R., Meng, F., Uysal, M., \& Mihalik, B. (2013). Understanding China's long-haul outbound travel market: An overlapped segmentation approach. Journal of Business Research, 66(6), 786-793.

Liew, V. K. S. (2020). The effect of novel coronavirus pandemic on tourism share prices. Journal of Tourism Futures. https://doi. org/10.1108/JTF-03-2020-0045.

McDowall, S. (2010). International tourist satisfaction and destination loyalty: Bangkok, Thailand. Asian Pacific Journal of Tourism Research, 15(1), 21-42.

Moutinho, L. (2000). Consumer Behavior. In: L. Moutinho (Ed.), Strategic Development in Tourism (pp. 41-79). New York, NY: CABI Publishing.

Mulyono, H., Hadian A., Purba, N. P., Pramono, R. (2020) Effect of Service Quality Toward Student Satisfaction and Loyalty in Higher Education. Journal of Asian Finance, Economics and Business, 7(10), 929-938. https://doi.org//jafeb.2020.vol7. no10.929

Murdy, S., Alexander, M., Bryce, D. (2018). What pulls ancestral tourists 'home'?: An analysis of ancestral tourist motivations. Tourism Management, 64, 13-19.

Nasution, H. N., \& Mavondo, F. T. (2008). Customer value in the hotel industry: what managers believe they deliver and what customer experience. International Journal of Hospitality Management, 27(2), 204-213.

Neuts, B., Romao, J., Leeuwen, V. E., Nijkamp, P. (2013). Describing the relationships between tourist satisfaction and destination loyalty in a segmented and digitalized market. Tourism Economics, 19(5), 987-1004. 
Oh, H. C., Uysal, M., \& Weaver, P. (1995). Product bundles and market segments based on travel motivations: A canonical correlation approach. International Journal of Hospitality Management, 14(2), 123-137.

Oliver, R. L. (1999). Whence consumer loyalty?. Journal of Marketing, 63, 33-44.

Oppermann, M. (2000). Tourism destination loyalty. Journal of Travel Research, 39, 78-84.

Prakoso, J. R. (2020). August, Bali Tourism Drops 81\% Due to Corona. accessed 12 Oktober 2020, retrieved from https:// travel.detik.com/travel-news/d-5160460/agustus-pariwisatabali-anjlok-81-akibat-corona.

Prayag, G., \& Hosany, S. (2014). When Middle East meets West: Understanding the motives and perceptions of young tourists from United Arab Emirates. Tourism Management, $40,35-45$.

Rohman, F. (2020). Determining Adventure Tourist Loyalty: Mediating Role of Tourist Satisfaction and Quality of Life. Journal of Asian Finance, Economics and Business, 7(10), 255-265 https://doi.org//jafeb.2020.vol7.no10.255

Sadeh, E., Asgari, F., Mousavi L., Sadeh, S. (2012). Factors affecting tourist satisfaction and its consequences. Journal of Basic and Applied Scientific Research, 2(2), 1557-1560.

Sekaran, U. S., \& Bougie, R. (2013). Research methods for business: A skill-building approach (6th ed.). Hoboken, NJ: John Wiley \& Sons.

Sirgy, M. J. (2010). Toward a quality of life theory of leisure travel satisfaction. Journal of Travel Research, 49(2), 246-260. doi: $10.1177 / 0047287509337416$

Solomon, M. (2009). Consumer behavior: buying, having, and being. Upper Saddle River, NJ: Pearson Education.
Swanson, K. K., \& Horridge, P. E. (2006). Travel motivations as souvenir purchase indicators. Tourism Management, 27 (4), 671-683.

Um, S., Chon, K., \& Ro, Y. (2006). Antecedents of revisit intention. Annals of Tourism Research, 33(4), 1141-1158.

UNESCO. (2018). UNESCO | Teaching and Learning for a Sustainable Future | Module 16: Sustainable tourism, 14-17. Retrieved from http://www.unesco.org/education/tlsf/mods/ theme_c/mod16.html

Uysal, M., \& Hagan, L. R. (1993). Motivation of pleasure to travel and tourism. In: M. A. Khan, M. D. Olsen, \& T. Var (Eds.), VNR'S encyclopedia of hospitality and tourism (pp. 798-810). New York, NY: Van Nostrand Reinhold.

Uysal, M., \& Noe, F. (2003). Satisfaction in outdoor recreation and tourism settings. In: E. Laws (Ed.), Case studies in tourism marketing (pp. 140-158). London, UK: Continuum Publisher.

Valle, P. O. D., Silva, J. A., Mendes, J., Guerreiro, M. (2006). Tourist satisfaction and destination loyalty intention: A structural and categorical analysis. International Journal of Business Science and Applied Management, 1(1), 25-44.

Weaver, D. B., \& Lawton, L. J. (2011). Visitor loyalty at a private South Carolina protected area. Journal of Travel Research, 50(3), 335-346. doi: 10.1177/0047287510362920

Yoon, Y. \& Uysal, M. (2005). An examination of the effects of motivation and satisfaction on destination loyalty: A structural model. Tourism Management, 26, 45-56.

Yuliana. (2018). Analysing Destination Experience, Satisfaction and Loyalty of Domestic Tourists: A Case Study of Bali, Indonesia. Pertanika Journals of Social Sciences and Humanities, 26, 213-224. 